> Innlegg på inntil $\mathbf{4 0 0}$ ord lastes opp i http://mc.manuscriptcentral.com/tidsskriftet.

Redaksjonen forbeholder seg retten til å foreta redaksjonelle endringer.

Forfattere av vitenskapelige artikler har tilsvarsrett (jf. Vancouver-gruppens regler).

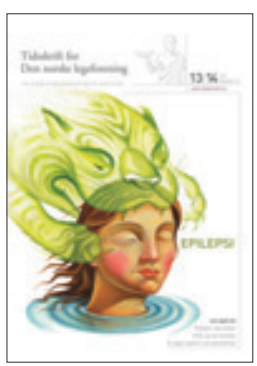

\section{Fortsatt galt om Kant}

I et brev til redaktøren i Tidsskriftet nr. 13-14/2011 svarer Tale Litleré Bjerknes og May-Britt Moser på min kritikk av deres bruk av Kant (2). De innrømmer «at referansen til medfødte egenskaper var upresis». Min påstand var imidlertid ikke at de hadde uttalt seg upresist, men at det de sa i intervjuet (3) var galt. Nå gjentar de den samme feilaktige påstanden, denne gangen ved å appellere til «Kant-eksperten Linda Palmer», som i den ledsagende artikkelen til deres i Science hevdet: «Kant believed he had established the a priori (and not merely innate) status of space as a «transcendental condition» of our representation of the world» (4). At det aprioriske ikke «bare er medfødt», må bety at Palmer og Lynch mener at det aprioriske er medfødt (pluss noe mer). Men dette er, som jeg viste ved sitater fra Kant, galt. Kant trodde selvsagt at det finnes en medfødt evne i mennesker som gjør det mulig for oss (i motsetning til rotter) å erverve den aprioriske (rene) romforestillingen, som er en transcendental mulighetsbetingelse for alle øvrige forestillinger om verden, men ikke at denne transcendentale betingelsen (eller noen andre kunnskapselementer som han betegner som «a priori») er medfødt. Min kritikk bygger for øvrig ikke på en antakelse om at hjerneforskerne «med representasjoner mener det samme som Kant», slik Bjerknes \& Moser hevder.

Palmer \& Lynch tror at Kant sannsynligvis ville vært «fascinated and delighted» av de nevrofysiologiske undersøkelsene. Kanskje det - han var også en stor naturvitenskapsmann, men neppe fordi han ville ha kunnet mene at forskernes resultater støtter hans kunnskapsteori fremfor konkurrerende filosofiske kunnskapsteorier.
Det er fint at naturvitere er opptatt av filosofiske diskusjoner, men jeg har vanskelig for å se at den filosofiske tilnærmingen til nevrobiologien som hjerneforskerne ved Norges teknisk-naturvitenskapelige universitet og deres amerikanske kolleger legger opp til, er fruktbar.

\section{Jens Saugstad \\ jens.saugstad@ifikk.uio.no \\ Universitetet i Oslo}

Jens Saugstad (f. 1956) er dr.philos. og professor i filosofi.

Ingen oppgitte interessekonflikter.

\section{Litteratur}

1. Bjerknes TL, Moser M-B. På kant med Kant. Tidsskr Nor Legeforen 2011; 131: 1278

2. Saugstad J. Galt om Kant. Tidsskr Nor Legeforen 2011; 131: 1072.

3. Hem E. Kartlegging av hjernens navigasjonssystemer. Tidsskr Nor Legeforen 2011; 131: 654.

4. Palmer L, Lynch $G$. A Kantian view of space. Science 2010; 328: 1487-8.

\section{Kunnskap om kunnskapen}

Torgeir Bruun Wyller går i Tidsskriftet nr. $12 / 2011$ til felts mot det han betegner som «vulgærcochranisme» (1). Han presenterer en original variant av «evidenspyramiden», hvor elektronisk beslutningsstøtte og retningslinjer blandes med nivåene for å gradere kvaliteten på faglig dokumentasjon. Han skriver: «Ved medisinsk embetseksamen i Oslo har det sågar vært foreslått at studentene skal kunne gjengi pyramidens nivåer og det tilhørende nummereringssystemet for rangering av evidens.» $\mathrm{Vi}$ stiller oss spørrende til Wyllers antydning om at undervisning i kunnskapshåndtering er uttrykk for «vulgærcochranisme».

Kunnskapshåndtering, ledelse og kvalitetsforbedring (KLoK) er et fag i profesjonsstudiet i medisin ved Universitetet i Oslo (2), der det bl.a. legges vekt på at kunnskapsbasert praksis er basert på en kombinasjon av forskningsbasert kunnskap, klinisk ekspertise og pasientens preferanser. Et av læringsmålene i KLoK er at studenten skal kunne forklare hvordan man søker etter forskningsbasert informasjon og hvordan man vurderer sannhetsverdien og relevansen av slik informasjon. Studenten skal også kunne vurdere kvaliteten på fagprosedyrer, kliniske retningslinjer og oppslagsverk.

Nivåene for å gradere faglig dokumentasjon er noe studentene møter alt som ferske leger. Eksempelvis er den nye nasjonale retningslinjen om behandling og rehabilitering ved hjerneslag basert på en slik gradering (3). Kunnskap om kunnskapen er en forutsetning for at medisinstudenter skal kunne ha et selvstendig, kritisk og reflektert forhold til kunnskapsgrunnlaget i eget fag. Etter å ha gjennomført seks års universitetsstudier i medisin bør en student kunne gjøre rede for etablerte nivåer for å gradere kvaliteten på faglig dokumentasjon.

\section{Jan C. Frich}

jancf@medisin.uio.no

Per Olav Vandvik

Institutt for helse og samfunn

Universitetet i Oslo

Jan C. Frich (f. 1970) er dr.med. og førsteamanuensis ved Avdeling for helseledelse og helse$\emptyset$ konomi, Institutt for helse og samfunn, Universitetet i Oslo, og er undervisningsleder i faget Kunnskapshåndtering, ledelse og kvalitetsforbedring. Han er spesialist i nevrologi og rådgiver/overlege ved Oslo universitetssykehus.

Ingen oppgitte interessekonflikter.

Per Olav Vandvik (f. 1968) er dr.med. og førsteamanuensis ved Avdeling for allmennmedisin, Institutt for helse og samfunn, Universitetet i Oslo. Han er forsker ved Kunnskapssenteret og konstituert overlege ved Medisinsk avdeling. Sykehuset Innlandet, Gjøvik. Ingen oppgitte interessekonflikter.

Litteratur

1. Wyller TB. Evidensbasert medisin eller vulgærcochranisme? Tiddskr Nor Legeforen 2011; 131 : 1181-2.

2. Det medisinske fakultet, Universitetet i Oslo. Fagsiden for Kunnskapshåndtering, ledelse og kvalitetsforbedring (KLoK): www.med.uio.no/ studier/ressurser/fagsider/klok (23.6.2011).

3. Behandling og rehabilitering ved hjerneslag. IS-1688. Oslo: Helsedirektoratet, 2010. 